\title{
BASELINE LABORATORY PARAMETERS FOR ASSESSMENT OF IRON DEFICIENCY IN PATIENTS WITH INFLAMMATORY BOWEL DISEASES
}

\author{
Vanda Sargautiene ${ }^{1,3, \#}$, Alevtina Leice ${ }^{2}$, and Didzis Gavars $^{3}$ \\ ${ }^{1}$ Faculty of Medicine, University of Latvia, 3 Jelgavas Str., Rīga, LV-1004, LATVIA \\ ${ }^{2}$ Pauls Stradinšs Medical College, University of Latvia, 38 Vidus Av., Jūrmala, LV-2010, LATVIA \\ ${ }^{3}$ E. Gulbis Laboratory, 366 Brīvības Str., Rīga, LV-1006, LATVIA \\ \# Corresponding author, vandasarg@outlook.com
}

Communicated by Renāte Ligere

\begin{abstract}
Iron deficiency (ID) and its late stage, iron deficiency anaemia, are often overlooked conditions in patients with inflammatory bowel disease (IBD). The study is primarily aimed at the need for firstphase screening for ID in patients with IBD using laboratory baseline parameters such as ferritin and C-reactive protein (CRP). Laboratory data of 4558 unique patients with IBD was analysed. For first-phase screening of ID, the thresholds of serum ferritin $<30 \mu \mathrm{g} / \mathrm{l}$ in the absence of inflammation (CRP $<5 \mathrm{mg} / \mathrm{l})$ and serum ferritin $<100 \mu \mathrm{g} / \mathrm{l}$ in the presence of inflammation (CRP $>5$ $\mathrm{mg} / \mathrm{ll}$ ) were used. The study revealed that ferritin analysis was conducted for only one third of the enrolled unique patients with IBD over a five-year period. First-phase ID screening showed that decrease in ferritin values was found in $56 \%$ of unique IBD patients over this period, as determined using CRP and ferritin during the same blood collection (same referral number). Haemoglobin $(\mathrm{Hb})$ tests were performed in $93 \%$ of unique IBD patients in the five-year period. A decrease in $\mathrm{Hb}$ was found in $21 \%$ of unique patients with Crohn's disease, $20 \%$ of patients with ulcerative colitis, and in 5\% of patients with unspecified non-infective gastroenteritis and colitis.
\end{abstract}

Keywords: ferritin, C-reactive protein, inflammation, haemoglobin, iron deficiency anaemia.

\section{INTRODUCTION}

Inflammatory bowel disease (IBD) is a chronic idiopathic inflammatory disorder affecting the small and large intestine. The International Statistical Classification of Diseases and Related Health Problems (ICD) divides IBD into three main groups: ulcerative colitis (UC), which is characterised by inflammation of the colon, Crohn's disease (CD), with transmural inflammation, which can affect any part of the gastrointestinal tract (Antunes et al., 2015), and unspecified non-infective gastroenteritis and colitis (IBDU), which is diagnosed when the disease has features of both UC and CD (Geboes, 2008).

In patients with IBD, inflamed mucosa often causes bleeding, which can lead to increased iron loss (Niepel et al., 2018). Additionally, loss of appetite during flaring disease and other factors such as medications used for IBD treatment (e.g., proton pump inhibitors, sulfasalazine, metho- trexate and thiopurines) also have negative effect on iron absorption and erythropoiesis (Nielsen et al., 2018).

Iron is a component of heme proteins, which carry or store oxygen and are essential for the function of all organs (Ueda and Takasawa, 2018). Iron are present in heme enzymes, non-heme iron enzymes, and iron-sulfur proteins that regulate various cell functions including electron transport in mitochondrial respiration, redox reactions and DNA synthesis (Geissler and Singh, 2011; Ueda and Takasawa, 2018).

At an early stage, non-anaemic iron deficiency (termed also as latent or subclinical iron deficiency), may manifest a normal haemoglobin and full blood count and, may often be asymptomatic and go undiagnosed for a long period of time. Suspicion should be raised if a patient with a normal complete blood count (CBC) develops symptoms of iron deficiency anaemia, especially if the medical history indicates a 
risk of iron deficiency (Sawada et al., 2014; Camaschella, 2015). Latent iron deficiency may be responsible for "nonhaematological" symptoms such as hair loss, paraesthesia of the hands and feet and reduction in cognitive function (Stein and Dignass, 2013).

Minimum required parameters for screening iron deficiency or anaemia at an early stage in patients with IBD should include complete blood count (CBC), C-reactive protein (CRP), and serum ferritin (Dignass et al., 2015).

Serum ferritin is a measure of stored iron content in the reticuloendothelial system, decreased serum ferritin is a good indicator of pre-latent iron deficiency when iron stores are depleted (Krawiec and Pac-Kożuchowska, 2020). In absolute iron deficiency, the serum ferritin concentration is < $15 \mathrm{ng} / \mathrm{ml}$ (Stein, 2013). The serum biomarkers C-reactive protein (CRP) and ferritin are positive acute-phase proteins, and they rise dramatically as part of the inflammatory response, mediated by increased expression of cytokines such as IL-6 (Dignass et al., 2018). As a result, this is reflected with normal or even high levels despite decreased availability of iron in the circulation (Cappellini, et al., 2020). Therefore, in the presence of inflammation, ferritin no longer correlates with iron availability (Dignass et al., 2018).

Consequently, the European Crohn's and Colitis Organisation (ECCO) Statement of Anaemia (1D) states that diagnostic criteria for iron deficiency depend on the level of inflammation (Dignass et al. 2015). In IBD, measurement of CRP (with a threshold of $5 \mathrm{mg} / \mathrm{l}$ ), or use of stool markers such as calprotectin or lactoferrin, has been recommended to confirm whether the disease is active or in remission (Dignass et al., 2018).

In patients without clinical, endoscopic, or biochemical evidence of active disease, serum ferritin $<30 \mu \mathrm{g} / \mathrm{l}$ is an appropriate criterion for evaluation of iron deficiency. In the presence of inflammation, a serum ferritin level up to $100 \mu \mathrm{g} / \mathrm{l}$ may still be consistent with iron deficiency (Dignass et al., 2015).

Untreated iron deficiency can therefore lead to iron deficiency anaemia (IDA), which manifests as changes in cognitive performance, reduced exercise capacity, and myocardial structural and functional changes (Fava et al., 2019). IDA can affect the capacity to have an adequate immune response (Hassan, et al., 2016). It has been noted that anaemia leads to a significant deterioration in the patient's quality of life, increased time lost at work and more frequent hospitalisation (Stein et al., 2010; Stein and Dignass, 2013). According to the World Health Organisation (WHO), anaemia is defined as a haemoglobin level $<13 \mathrm{~g} / \mathrm{dl}$ in men and $<12$ $\mathrm{g} / \mathrm{dl}$ in women (WHO, 2011). The same cut-off values for anaemia have been reported in patients with IBD and healthy individuals (Dignass et al., 2015).

Anaemia workup in patients with IBD should be initiated if the haemoglobin is below normal. The minimum workup includes red blood cell indices such as red cell distribution width (RDW) and mean corpuscular volume (MCV), reticulocyte count, differential blood cell count, serum ferritin, transferrin saturation (TfS), and CRP concentration (Dignass et al., 2015).

A recent study showed that more than a half of patients with IBD $(55 \%)$ developed anaemia after diagnosis of the disease, with $25 \%$ developing moderate to severe anaemia, and that the incidence rate of anaemia was $85 \%$ higher in a IBD cohort than matched non-IBD patients (Patel et al., 2019).

Another study reported that of 836 newly diagnosed patients with ulcerative colitis (UC) in 585 patients (70\%) developed anaemia over the course of a median eight years of follow-up. More than one-third of anaemic UC patients were not tested for ID. Once tested, almost a quarter of the patients with IDA were not treated with iron replacement therapy (Khan et al., 2016). A review study showed the prevalence of anaemia in patients with IBD had a range of $16-74 \%$, with a mean value of $16 \%$ in outpatients and $68 \%$ in hospitalised patients (Gisbert and Gomollon, 2008).

It is recommended that treatment of ID and IDA should not be overlooked and should be started as soon as possible in patients with IBD (Eliadou et al., 2017). The European Crohn's and Colitis Organisation (ECCO) Statement of Anaemia (1B) recommends anaemia screening for patients with IBD in remission or mild disease every 6 to 12 months (Dignass et al., 2015).

Although many studies show that ID with or without anaemia is a common and often underestimated problem in IBD patients, the problem of ID and IDA in patients with IBD in Latvia remains unexplored.

Taking into account the urgency of the problem of ID among patients with IBD, as well as the results of the latest data, which indicate that the prevalence of UC and CD in Latvia is increasing (Mirzajanova et al., 2020), this study was designed to analyse data of first-phase screening for ID using baseline laboratory parameters (CRP and ferritin) in a group of IBD patients in Latvia over a five-year period (2015-2019).

\section{METHODS}

Patient inclusion and laboratory data analysis. The conducted research was based on data obtained in an accredited clinical laboratory, E. Gulbis Laboratory (EGL) (LVS EN ISO 15189:2013, ISO/IEC 17025, Rīga, Latvia), which provides laboratory services in all regions of Latvia and practically represents the overall Latvian population (Gavars et al., 2019). Laboratory analyses were performed in accordance with a quality control programme and in accordance with the user manuals of analysers and reagent manufacturers.

Data generation was carried out using the EGL information system, which tracks and stores clinical details about patients during lab visits. All patient data used in the study 
were pseudo-depersonalised. Our study included data on patients with inflammatory bowel disease (IBD) who underwent blood testing (complete blood count, ferritin values, C-reactive protein (CRP)) in the period from January 2015 to December 2019.

Patients with previously classified diagnoses such as Crohn's disease (CD), ulcerative colitis (UC), and unspecified non-infective gastroenteritis and colitis (IBDU) were enrolled in the study. Diagnoses were identified using International Statistical Classification of Diseases and Related Health Problems (ICD) codes for UC (ICD-10 K51.XX), CD (ICD-10 K50.XX), and IBDU (ICD-10 K52.XX).

In addition, the diagnosis of iron deficiency anaemia (ICD10 D50) as a comorbidity was taken into account to determine its prevalence among patients with IBD. The values of the analysed biomarkers were included from the period when the patient IBD diagnosis was entered in the EGL database.

Unique patients were identified based on the unique number registered in the laboratory, which was assigned to the patient after the patient's first registered visit to the laboratory and remained unchanged in subsequent analysis, regardless of time. Patient information such as age, gender, diagnosed were included into the study. Data were analysed by applying a step-by-step exclusion algorithm.

The study protocol was approved by the Research Ethics Committee of the Institute of Cardiology and Regenerative Medicine of the University of Latvia.

Measurements. Taking into account possible inaccuracies in the interpretation of ferritin levels in patients with IBD during an inflammatory state, first-phase screening for ID was interpreted on the basis of C-reactive protein (CRP) and serum ferritin values during the same blood collection (same referral number) in accordance with recommendations of the European Crohn's and Colitis Organisation (ECCO) for the diagnosis ID.

Patients with IBD over 18 years old with CRP and ferritin tests listed under the same referral number were divided into two groups: CRP $<5 \mathrm{mg} / \mathrm{l}$ (group I) and CRP $>5 \mathrm{mg} / \mathrm{l}$ (group II). Iron deficiency was defined according to ECCO recommendations for the diagnosis of ID: serum ferritin threshold level of $<30 \mu \mathrm{g} / \mathrm{l}$ in the absence of inflammation (group I) or serum ferritin threshold of $<100 \mu \mathrm{g} / \mathrm{l}$ in the presence of inflammation (group II).

Laboratory values of haemoglobin $(\mathrm{Hb})$ were analysed in accordance with the WHO definition of anaemia (WHO, 2011) depending on the gender and age of the patient.

Other biomarkers, such as $\mathrm{MCV}, \mathrm{MCH}, \mathrm{MCHC}$, transferrin etc. and their frequency of prescription were also analysed to determine the routine referral trends for screening of IDA.

All reference values of biomarkers take into account the gender and age of the patients.

Statistical analysis. SPSS 22 (IBM SPSS Statistics for Windows, Version 22.0. IBM Corp.) was used for statistical analysis. Categorical variables are presented as percentages, while continuous variables are presented as the mean \pm SD.

One-way analysis of variance (ANOVA) and the Post-hoc Tuckey test were used to determine differences between the means of independent groups.

Simple linear regression analysis was used to detect associations between serum ferritin and CRP.

All statistical tests were two-tailed, and a $p$ value $<0.05$ was considered statistically significant.

\section{RESULTS}

Data of 4558 unique patients with IBD (with ICD codes K50.0-K50.9, K51.0-K51.9, K52.0-K52.9) were obtained from the EGL database for a period of five years (from 1 January 2015 till 31 December 2019). Of these patients, 741 patients were diagnosed with CD (female $n=411$ and male $\mathrm{n}=330$ ); 1693 were diagnosed with UC (female $\mathrm{n}=957$ and male $n=736$ ); and 2124 were diagnosed with IBDU (female $n=1267$ and male $n=857$ ). The age distribution of included unique patients with IBD based on subtypes of IBD is shown in Figure 1.

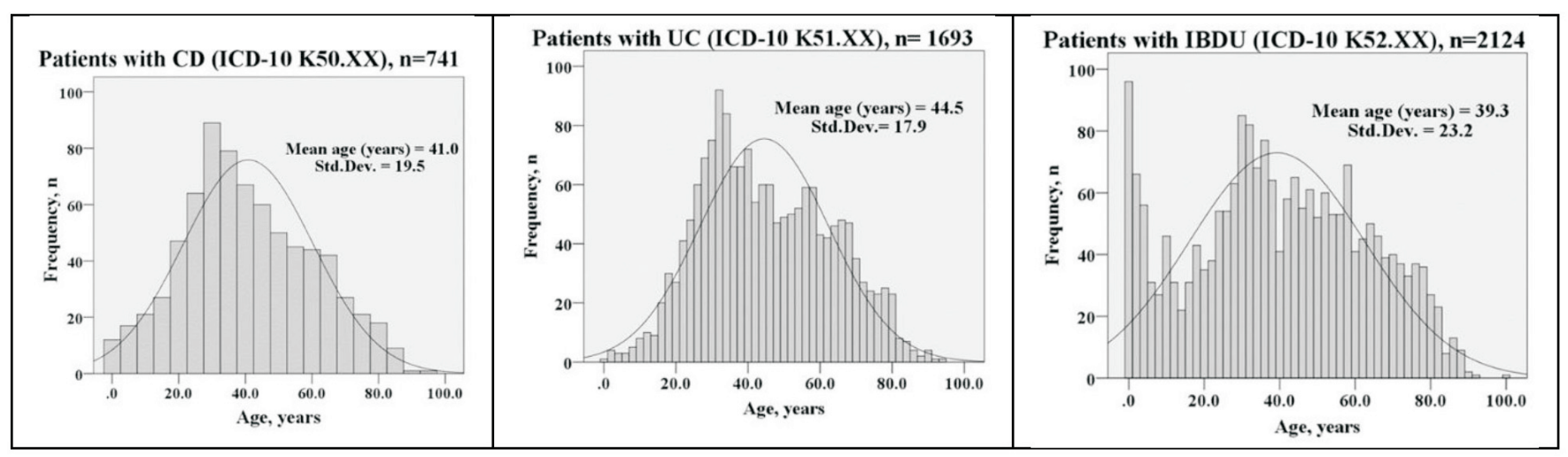

Fig. 1. Distribution of age (years) by frequencies (n) of included patients based on subtypes of inflammatory bowel diseases. CD, Crohn's disease; UC:, ulcerative colitis; IBDU, unspecified non-infective gastroenteritis and colitis. Between 1 January 2015 and 31 December 2019 , 4558 unique patients with IBD-associated ICD code were identified in the EGL database. 
Comorbidity with iron deficiency anaemia (D50) in patients with IBD was the most frequently reported diagnosis of anaemia (based on ICD codes D50-D53), accounting for $84 \%$ of all anaemia diagnoses (of 98 reported cases of anaemia, 82 were IDA).

IDA as a comorbidity was reported on average in $3 \%(\mathrm{n}=$ $20)$ of unique patients with $C D$, in $3 \%(n=43)$ of patients with $\mathrm{UC}$, and only in $1 \%(\mathrm{n}=19)$ of unique patients with IBDU in the five-year period (from January 2015 to December 2019).

A detailed annual analysis of IDA diagnoses showed that the percentage of IDA cases during a given year was twice as high (on average $6 \%$ of unique patients with $\mathrm{CD}$ and $\mathrm{UC}$, and $2 \%$ patients with IBDU), which indicates that these patients were not diagnosed with IDA as single cases per year, but as a continuation or recurrent IDA diagnosis within the five years.

Decreased values of haemoglobin $(\mathrm{Hb})$ over the five-year period were found in $154(21 \%)$ unique patients with $\mathrm{CD}$, in $332(20 \%)$ UC patients and only in $115(5 \%)$ in patients with IBDU. Multiple comparison of $\mathrm{Hb}$ values between IBD subgroups (CD, UC and IBDU) showed significant differences between them $(p<0.005)$.

The total number of $\mathrm{Hb}$ analyses performed over the five-year period in patients with IBD was 25521 tests, of which 4233 (females $=2566$, males $=1667$ ) were performed in unique patients with IBD. The mean $\mathrm{Hb}$ value in females was $131.78 \pm 14.21 \mathrm{~g} \cdot \mathrm{l}^{-1}$, in males $150.35 \pm 15.80$ $\mathrm{g} \cdot \mathrm{l}^{-1}$. According to the $\mathrm{WHO}$, decreased $\mathrm{Hb}$ values are found in anaemia states (WHO, 2011), but in the presence of reduced $\mathrm{Hb}$ values, anaemia workup in patients with IBD should be initiated, which should include analysis of reticulocyte count, serum ferritin, and transferrin saturation (Dignass et al., 2015).

Serum ferritin analysis were performed over the five-year period in 494 tests in 240 unique patients with CD (females $=146$, males $=94), 1137$ tests were performed in 591 unique patients with $\mathrm{UC}$ (females $=220$, males $=371$ ), and 224 tests performed in 216 unique patients with IBDU (females $=158$; males $=58$ ).

Only $28 \%(\mathrm{n}=205)$ of unique patients over 18 years of age with $\mathrm{CD}, 16 \%(\mathrm{n}=277)$ of unique patients with UC, and $5 \%(\mathrm{n}=112)$ with IBDU were referred for CRP and ferritin tests in same referral number at least once within the fiveyear period (Fig. 2, A-C). Of which 63\% $(\mathrm{n}=130)$ patients with $C D, 60 \%(n=165)$ with $U C$, and $44 \%(n=49)$ with IBDU had decreased ferritin values based on first-phase screening (Fig. 2, A-C).

In patients with $\mathrm{CD}, \mathrm{CRP}$ had significant linear dependence on ferritin, $b=4.9$, p 0.001. Significant linear dependence of CRP on ferritin value was also found in patients with UC $\mathrm{b}=1.4, p<0.001$, but in this group the regression coefficient was lower. There was no established significant de-

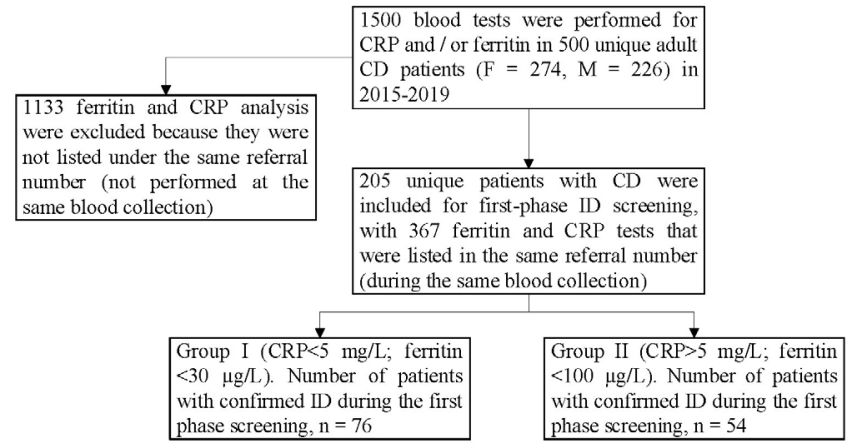

A

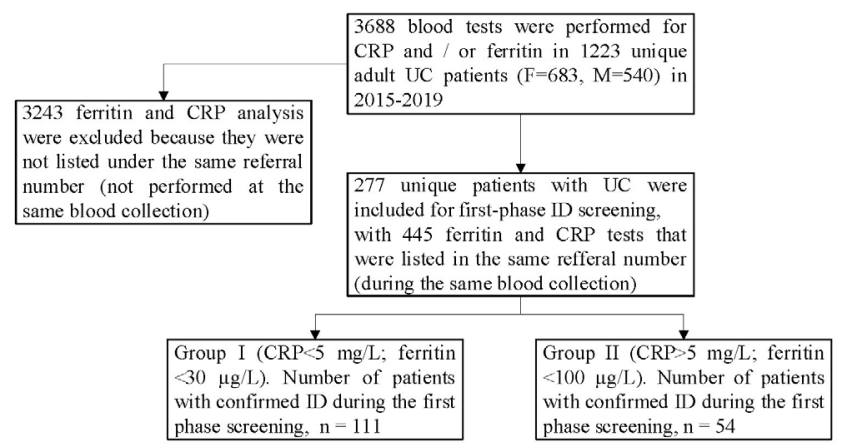

B phase screening, $n=54$

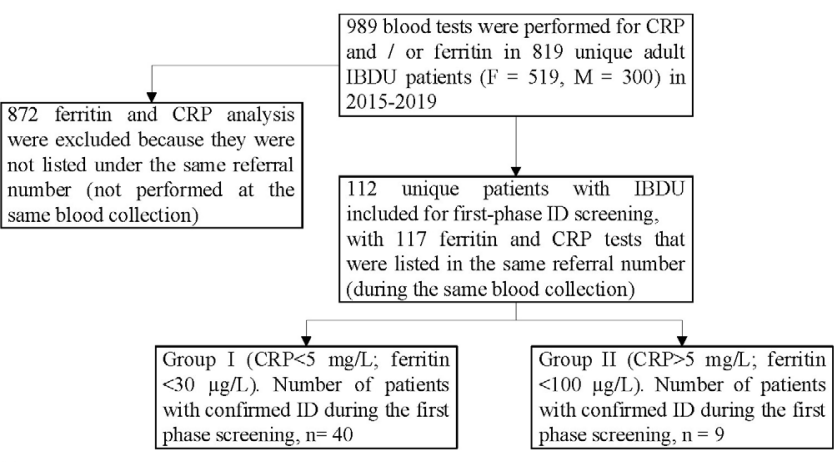

C

Fig. 2. Flowcharts for determination of first-phase screening of iron deficiency (ID) in patients with Crohn's disease: CD (A), ulcerative colitis: UC (B), unspecified non-infective gastroenteritis and colitis (IBDU) (C) based on performed CRP and serum ferritin analyses. A serum ferritin threshold $<30 \mu \mathrm{g} / \mathrm{l}$ in the absence of inflammation (group I) or a serum ferritin threshold of $<100 \mu \mathrm{g} / \mathrm{l}$ in the presence of inflammation (group II) were analysed according to the recommendations of the European Crohn's and Colitis Organisation for the diagnosis of ID.

pendence between CRP and ferritin in patients with IBDU, $\mathrm{b}=1.3, p>0.05$.

Other blood markers for identifying ID and IDA are also widely used and are listed in the EGL database. Red blood cell indices such as low Mean Corpuscular Volume (MCV), Low Mean Corpuscular Haemoglobin $(\mathrm{MCH})$ and Mean Corpuscular Haemoglobin Concentration (MCHC). Over the five years, each of the parameters was performed in 24 648 tests for patients with IBD, encompassing 4232 unique patients, females $=2566$, males $=1666$ ). The mean MCV value of all tests performed was $88.98 \pm 5.98$ femtolitres (fl). Decreased MCV values were reported in 410 (9\%) unique IBD patients. Decreased $\mathrm{MCH}$ values were reported 
in 658 (14\%), and elevated MCH values were found in 214 $(5 \%)$ unique IBD patients. The mean $\mathrm{MCH}$ value of all tests performed was $29.33 \pm 2.80 \mathrm{pg}$. Mean MCHC value of all tests performed was $328.98 \pm 17.00 \mathrm{~g} / \mathrm{l}$. Decreased MCHC values were reported in $1020(22 \%)$, and elevated in 88 (2\%) unique patients with IBD.

Haematocrit (HTC) was analysed in 24663 tests for patients with IBD, of which 4231 referred to unique patients (females $=2566$, males $=1665)$. The mean HTC value of all performed tests was $40.92 \pm 4.78 \%$. Decreased HTC values were reported in 789 (17\%), and elevated in $233(5 \%)$ unique patients with IBD.

Transferrin analysis over the five years was performed in 225 tests for patients with IBD, encompassing 117 unique patients (females $=78$, males $=39$ ). The mean transferrin value of all performed tests was $3.00 \pm 0.67 \mathrm{~g} / \mathrm{l}$. Decreased transferrin values were reported in $5(0.1 \%)$, and elevated in $27(0.5 \%)$ unique patients with IBD.

Serum iron analyses over five years were performed in 2655 tests for patients with IBD, of which 1130 unique patients (females $=786$, males $=344$ ). Mean serum iron value of all performed tests was $13.45 \pm 8.47 \mathrm{~mol} / \mathrm{l}$. Decreased iron values were reported in 285 (6\%), and elevated values in 112 $(2 \%)$ unique patients with IBD.

\section{DISCUSSION}

This study primarily addresses the need for first-phase screening for iron deficiency (ID) using baseline laboratory parameters in patients with inflammatory bowel diseases (IBD).

Iron deficiency without anaemia (latent iron deficiency) where serum ferritin is reduced but haemoglobin and red cell indices are normal, is a diagnostic problem, because it can go unnoticed for a long time and there are no welldefined diagnostic criteria (Soppi, 2018).

As mentioned above, for patients with IBD the European Crohn's and Colitis Organisation (ECCO) recommends regular complete blood count (CBC), serum ferritin, and $\mathrm{C}$ reactive protein (CRP) tests depending on the disease activity for the timely diagnosis of ID. However, the results of our study showed that over the five-year period, baseline serum ferritin tests were performed only in $32 \%$ of unique patients with Crohn's disease (CD), in $35 \%$ of patients with ulcerative colitis (UC), and in $10 \%$ of unique patients with unspecified non-infective gastroenteritis and colitis (IBDU).

Only $22 \%$ of patients with CD and UC, and 5\% patients with IBDU were registered in the EGL database with tests for CRP and ferritin under the same referral number (analyses were performed during the same blood collection). However, these baseline markers may be a good option for the first-phase of ID screening, since the threshold values for ferritin depending on CRP, proposed by ECCO, is easy to interpret and inexpensive to use in clinical practice.
Based on CRP and ferritin thresholds, our study found that $63 \%$ of CD patients, $60 \%$ UC and $44 \%$ IBDU patients, in whom CRP and ferritin values were analysed in one blood sample, had decreased ferritin values over the five-year period. This is a minimum screening requirement proposed by $\mathrm{ECCO}$, and in cases of positive first-phase screening further screening should be continued using other markers for precise ID recognition. Additional tests, such as iron binding capacity, transferrin saturation, and serum soluble transferrin receptor may be required to definitively exclude iron deficiency. However, lack of standardisation between available assays in chronic diseases limits wide use in clinical practice (Cappellini et al., 2020).

Iron deficiency anaemia (IDA) is a complication of untreated ID, and the most common anaemia in patients with IBD (Niepel et al., 2018). We analysed prevalence of IDA as a comorbidity in patients with IBD based on the EGL laboratory database. Although the results of our study showed IDA as a comorbidity in the referral list, analysis was reported only in $3 \%$ of unique IBD patients. IDA was the most commonly reported anaemia in patients with IBD ( $84 \%$ of all reported anaemia diagnoses).

We assume that the number of patients with IDA may be much higher, and low rates of patients with IBD and IDA, specified in current study as a comorbidity, do not indicate the absence of a problem, but, on the contrary, it appears that in patients with IBD with chronic inflammatory condition, iron deficiency and anaemia may be often overlooked. A previous study also showed that more than one-third of patients with UC were not tested for IDA (Khan et al., 2016).

The diagnosis of IDA can be readily made by assessing haemoglobin and serum ferritin levels (Cappellini et al., 2020). In our study, haemoglobin $(\mathrm{Hb})$ tests were performed in $93 \%$ of unique IBD patients within the five-year period. The results of our study showed that cases of decreased $\mathrm{Hb}$ values in patients with Crohn disease (CD) and ulcerative colitis (UC) reached $20 \%$, and only $5 \%$ in patients with unspecified non-infective gastroenteritis and colitis (IBDU).

In the presence of reduced haemoglobin values, anaemia workup in patients with IBD should be initiated, which should include reticulocyte count, serum ferritin, and transferrin saturation tests (Dignass et al., 2015).

Red blood cell indices such as low mean corpuscular volume (MCV) and low mean corpuscular haemoglobin $(\mathrm{MCH})$ are commonly considered when diagnosing iron deficiency. MCV is a laboratory value that measures the average size and volume of a red blood cell. Anaemia is classified based on the MCV into microcytic, normocytic, or macrocytic anaemia. Iron deficiency anaemia, which is normocytic in early stages and microcytic in later stages, is the most common type of anaemia worldwide (Faruqi and Mukkamalla, 2020 ). 
In chronic iron-deficient anaemia, anaemia of chronic disease, sideroblastic anaemia, thalassaemias and other conditions its measure is under $80 \mathrm{fl}$ while normal MCV is between 80 to $100 \mathrm{fl}$ (Maner and Moosavi, 2020).

Our study results showed that $9 \%$ of unique IBD patients had decreased MCV values, which indicates the possibility of microcytic anaemia. However, as mentioned earlier, these values may be normocytic in the early ID stage, so the total number of patients with pre-latent ID stage may be higher.

$\mathrm{MCH}$ is the weight of one red cell, and a normal $\mathrm{MCH}$ value in humans is 27 to 31 picograms/cell. In iron deficiency anaemia the cell weight becomes lighter, and thus a $\mathrm{MCH} 27 \mathrm{pg}$ is an indication of iron deficiency. The MCH decreases when $\mathrm{Hb}$ synthesis is reduced, or when RBCs are smaller than normal, such as in cases of iron-deficiency anaemia (Sarma, 1990).

In our study, $14 \%$ of unique IBD patients had decreased $\mathrm{MCH}$ values. The standard parameters of iron deficiency, low MCV and low mean corpuscular haemoglobin (MCH) are generally reliable, however, iron deficiency as the cause of anaemia cannot be ruled out on the grounds of a normal MCV, since up to $40 \%$ of IDA cases are normocytic (e.g., in IBD patients treated with azathioprine or 6-MP) (Stein and Dignass, 2013).

Conversely, low MCV does not necessarily indicate ID, as the presence of anaemia of chronic disease can cause it to be normal or low (Stein and Dignass, 2013). Therefore, other parameters should be taken into account when assessing $\mathrm{MCV}$.

Another parameter of red blood cell indices, mean corpuscular haemoglobin concentration (MCHC), is the average weight of haemoglobin per cell per its volume; its normal value is $32-36 \mathrm{~g} / \mathrm{dl}$. MCHC is an estimation of the availability of iron over the preceding 90-120 days (Urrechaga et al., 2016). In our study, $22 \%$ of unique patients with IBD had decreased MCHC values.

However, changes in red cell indices occur late in the course of IDA in view of the red cell lifespan, and the usefulness of these tests may be limited (Cappellini et al., 2020).

Red blood cell distribution width (RDW) is a traditional haematological index used to explore the aetiology of anaemia. Iron-deficiency anaemia usually presents with high RDW and low MCV. A result in the normal range of RDW for an adult female is 11.9-15.5 per cent, for an adult male -11.8-15.6 per cent. However, studies indicate that RDW is also an inflammatory marker (Zhi-De $\mathrm{Hu}, 2016$ ), and this biomarker is a significant indicator for assessment of activity of UC (Cakal et al., 2009).

As seen, a number of biomarkers of iron status are used in the clinical practice. However, traditional biochemical parameters of iron depletion depend on inflammation, and therefore, the diagnosis of ID and IDA in presence of inflammation and chronic disease often is challenging.

It would therefore be useful to take into account the ECCO recommendations, which specify minimum screening frequencies using baseline laboratory parameters for the timely diagnosis of ID and reduce the risk of IDA and complications in patients with IBD.

\section{STUDY LIMITATIONS}

The study has some limitations, firstly, the algorithm for diagnosing IBD in included patients is unknown, or the diagnosis was confirmed by endoscopic or radiological examination.

Second, although the data on sex and age were taken into account, other factors such as ethnicity and smoking habit were not available. Possible other erythropoiesis diseases that could affect the rates of blood parameters were not considered. Finally, it is not known if the IBD patients underwent blood tests in other laboratories, and therefore the data may be underestimated or overestimated.

The strong point of the study is that, given the fact that EGL is the largest accredited laboratory in Latvia with the largest number of branches throughout Latvia, which are easily accessible to patients, we believe that the included data on IBD patients are reliable and represent the general situation in Latvia. This is also supported by the fact that in our study the number of unique IBD patients reached 4558, which was close to the results of another retrospective analysis from the Latvian National Health Service database (NHS) in the period 2012-2018, where 4828 patients with IBD associated ICD code were identified (Mirzajanova et al., 2020).

\section{FUTURE RESEARCH INSIGHTS}

Future research investigating the treatment of iron deficiency and its relationship to altered gut microbiota in patients with IBD may provide new insights and findings. Intestinal inflammation leads to a lack of iron absorption, and consequently iron excess from the intestinal environment can directly reach the intestinal microbiota. Iron is a critical nutrient for the growth of microorganisms, and many gut bacteria compete for the free iron to maintain their growth. Most of the pathogenic bacteria have enhanced iron acquisition mechanisms, which contribute to increased virulence (Lee et al., 2017).

Enterobacteriaceae species have been described as enhancing the inflammatory response, observed in IBD, and are known to have an increased ability to absorb iron (Baldelli et al., 2021 ). It was observed that dietary iron supplementation leads to disease exacerbation and a higher risk of infection, perhaps through alterations of commensal microbiota in IBD (Buret et al., 2019). 
Cytotoxicity of the unabsorbed iron on the gut cells (enterocytes) needs to be extensively addressed and tailored foods can bring an outstanding approach in iron deficiency treatment (Rusu et al., 2020).

Therefore, additional aspects of intestinal iron homeostasis during inflammatory conditions and the role of the gut microbiota in this pathway may provide new insights and solutions for optimal treatment of ID. Before starting iron supplementation, it would be appropriate to study in more detail the nutritional strategies and additional functional dietary components such as probiotics, prebiotics and synbiotics, which would primarily help regulate gut microbiota composition and intestinal inflammation in IBD.

\section{CONCLUSIONS}

In patients with inflammatory bowel diseases, regular screening for iron deficiency can help to diagnose ID early, before iron deficiency anaemia develops.

The study primarily addressed the need for first-phase screening for ID in patients with IBD using laboratory baseline parameters such as ferritin and C-reactive protein.

The study revealed that ferritin analysis was prescribed to only one-third of the enrolled unique patients with IBD over a five-year period. First-phase ID screening showed that a decrease in ferritin values was found in $56 \%$ of unique IBD patients over this period, as determined using CRP and ferritin during the same blood collection (same referral number).

Untreated ID can lead to IDA, which results in decreased haemoglobin values. Our study showed that $\mathrm{Hb}$ tests were performed in $93 \%$ of unique IBD patients within the fiveyear period. A decrease in $\mathrm{Hb}$ was found in $21 \%$ of unique patients with Crohn's disease, $20 \%$ of patients with ulcerative colitis, and $5 \%$ of patients with unspecified noninfective gastroenteritis and colitis.

Further screening should be continued using other markers to provide a precise ID diagnosis, and prevention and treatment strategies. In addition, more research is needed to determine the optimal dietary strategies for the prevention and/or treatment of ID in patients with IBD.

\section{AUTHORS' CONTRIBUTIONS}

V.S. - conceptualisation, methodology, investigation, data processing and analysis, writing original draft. A.L. - review and recommendations. D.G. - review and recommendations.

\section{REFERENCES}

Antunes, C. V., Hallack Neto, A. E., Nascimento, C. R., Chebli, L. A., Moutinho, I. L., Pinheiro, B., Reboredo, M. M., Malaguti, C., Castro, A. C., Chebli, J. M. (2015). Anemia in inflammatory bowel disease outpatients: Prevalence, risk factors, and etiology. BioMed. Res. Int., 728925.
Baldelli, V., Scaldaferri, F., Putignani, L., Chierico, Del Chierico, F. (2021). The role of Enterobacteriaceae in gut microbiota dysbiosis in inflammatory bowel diseases. Microorganisms, 9 (4), 697.

Buret, A. G., Motta, J. P., Allain, T., Ferraz, J., Wallace, J. L. (2019). Pathobiont release from dysbiotic gut microbiota biofilms in intestinal inflammatory diseases: A role for iron? J. Biomed. Sci., 26 (1), 1.

Cakal, B., Akoz, A. G., Ustundag, Y., Yalinkilic, M., Ulker, A., Ankarali, H. (2009). Red cell distribution width for assessment of activity of inflammatory bowel disease. Dig. Dis. Sci., 54 (4), 842-847.

Camaschella, C. (2015). Iron-deficiency anemia. New Engl. J. Med., 372 (19), 1832-1843.

Cappellini, M. D., Musallam, K. M., Taher, A. T. (2020). Iron deficiency anaemia revisited. J. Intern. Med., 287 (2), 153-170.

Dignass, A. U., Gasche, C., Bettenworth, D., Birgegård, G., Danese, S., Gisbert, J. P., Gomollon, F., Iqbal, T., Katsanos, K., Koutroubakis, I., Magro, F., Savoye, G., Stein, J., Vavricka, S. European Crohn's and Colitis Organisation [ECCO] (2015). European consensus on the diagnosis and management of iron deficiency and anaemia in inflammatory bowel diseases. J. Crohns. Colitis, 9 (3), 211-222.

Dignass, A., Farrag, K., Stein, J. (2018). Limitations of serum ferritin in diagnosing iron deficiency in inflammatory conditions. Int. J. Chronic. Dis., 2018, 9394060.

Eliadou, E., Kini, G., Huang, J., Champion, A., Inns, S. J. (2017). Intravenous iron replacement improves quality of life in hypoferritinemic inflammatory bowel disease patients with and without anemia. Dig. Dis., 35 (5), $444-448$.

Faruqi, A., Mukkamalla, S. (2021). Iron binding capacity. In: StatPearls [Internet]. Treasure Island (FL): StatPearls Publishing, PMID: 32644545.

Fava, C., Piepoli, M., Villani, G. Q. (2019). Heart failure and iron deficiency. Giornale Ital. Cardiol., 20 (3), 126-135.

Gavars, D., Perminov, D., Tauckels, E., Lindenberga, I., Auce, A., Lejniece, S. (2019). Association of elevated vitamin B12 with oncohematological diseases in a cohort of 79,524 patients from Latvia. Exp. Oncol., 41 (4), 357-362.

Geboes, K., Colombel, J. F., Greenstein, A., Jewell, D. P., Sandborn, W. J., Vatn, M. H., Warren, B., Riddell, R. H. (2008). Pathology task force of the International Oganization of Inflammatory Bowel Diseases. Indeterminate colitis: A review of the concept - what's in a name? Inflamm. Bowel Dis., 14 (6), 850-857.

Geissler, C., Singh, M. (2011). Iron, meat and health. Nutrients, 3 (3), 283-316.

Gisbert, J. P., Gomollón, F. (2008). Common misconceptions in the diagnosis and management of anemia in inflammatory bowel disease. Amer. J. Gastroenterol., 103 (5), 1299-1307.

Hassan, T. H., Badr, M. A., Karam, N. A., Zkaria, M., El Saadany, H. F., Abdel Rahman, D. M., Shahbah, D. A., Al Morshedy, S. M., Fathy, M., Esh, A., Selim, A. M. (2016). Impact of iron deficiency anemia on the function of the immune system in children. Medicine, 95 (47), e5395.

Hu, Z. D. (2016). Red blood cell distribution width: A promising index for estimating activity of autoimmune disease. J. Lab. Precis. Med., 1, 4.

Khan, N., Patel, D., Shah, Y., Yang, Y. X. (2016). Factors predicting testing and treatment of iron deficiency in a nationwide cohort of anemic UC patients. Inflamm. Bowel. Dis., 22 (12), 2894-2901.

Krawiec, P., Pac-Kożuchowska, E. (2020). Biomarkers and hematological indices in the diagnosis of iron deficiency in children with inflammatory bowel disease. Nutrients, 12 (5), 1358.

Lee, T., Clavel, T., Smirnov, K., Schmidt, A., Lagkouvardos, I., Walker, A., Lucio, M., Michalke, B., Schmitt-Kopplin, P., Fedorak, R., Haller, D. (2017). Oral versus intravenous iron replacement therapy distinctly alters the gut microbiota and metabolome in patients with IBD. Gut, 66 (5), $863-871$. 
Lopez, A., Cacoub, P., Macdougall, I. C., Peyrin-Biroulet, L. (2016). Iron deficiency anaemia. Lancet, 387 (10021), 907-916.

Maner, B. S., Moosavi, L. (2021). Mean corpuscular volume. In: StatPearls [Internet]. Treasure Island (FL): StatPearls Publishing. PMID: 31424859.

Mirzajanova, I., Purvina, S., Pokrotnieks, J. (2020). Incidence and prevalence of Crohn's disease and ulerative colitis (2013-2017) based on the Latvian Nationwide Medicines Reimbursement database. Proc. Latvian Acad. Sci., Section B, 74 (2), 138-143.

Nielsen, O. H., Soendergaard, C., Vikner, M. E., Weiss, G. (2018). Rational management of iron-deficiency anaemia in inflammatory bowel disease. Nutrients, 10 (1), 82.

Niepel, D., Klag, T., Malek, N. P., Wehkamp, J. (2018). Practical guidance for the management of iron deficiency in patients with inflammatory bowel disease. Therap. Adv. Gastroenterol., 11, 1756284818769074.

Patel, D., Yang, Y. X., Trivedi, C., Kavani, H., Xie, D., Medvedeva, E., Lewis, J., Khan, N. (2020). Incidence, duration, and management of anemia: A nationwide comparison between IBD and non-IBD populations. Inflamm. Bowel. Dis., 26 (6), 934-940.

Rusu, I. G., Suharoschi, R., Vodnar, D. C., Pop, C. R., Socaci, S. A., Vulturar, R., Istrati, M., Morosan, I., Färcas, A. C., Kerezsi, A. D., Muresan, C. I., Pop, O. L. (2020). Iron supplementation influence on the gut microbiota and probiotic intake effect in iron deficiency-a literature-based review. Nutrients, 12 (7), 1993.
Sawada, T., Konomi, A., Yokoi, K. (2014). Iron deficiency without anemia is associated with anger and fatigue in young Japanese women. Biol. Trace. Elem. Res., 159 (1-3), 22-31.

Soppi E. T. (2018). Iron deficiency without anemia: A clinical challenge. Clin. Case. Rep., 6 (6), 1082-1086.

Stein, J., Dignass, A. U. (2013). Management of iron deficiency anemia in inflammatory bowel disease: A practical approach. Ann. Gastroenterol., 26 (2), 104-113.

Stein, J., Hartmann, F., Dignass, A. U. (2010). Diagnosis and management of iron deficiency anemia in patients with IBD. Nat. Rev. Gastroenterol. Hepatol., 7 (11), 599-610.

Ueda, N., Takasawa, K. (2018). Impact of inflammation on ferritin, hepcidin and the management of iron deficiency anemia in chronic kidney disease. Nutrients, 10 (9), 1173

Urrechaga, E., Borque, L., Escanero, J. F. (2016). Clinical value of hypochromia markers in the detection of latent iron deficiency in nonanemic premenopausal women. J. Clin. Lab. Anal., 30 (5), 623-627.

Walker, H. K., Hall, W. D., Hurst, J. W. (Eds.). (1990). Clinical methods: The History, Physical, and Laboratory Examinations. $3^{\text {rd }}$ edition. Butterworths-Heinemann. 1087 pp.

World Health Organization (WHO) (2011). Haemoglobin concentrations for the diagnosis of anaemia and assessment of severity. Vitamin and mineral nutrition information system. World Health Organization, Geneva. https://apps.who.int/iris/bitstrea m/handle/10665/85839/ WHO_NMH_NHD_MNM_11.1_eng.pdf (accessed 01.07.2021).

Received 22 March 2021

Accepted in the final form 9 January 2022

\section{LABORATORIJAS PAMATPARAMETRI DZELZS DEFICĪTA NOVĒRTĒŠANAI PACIENTIEM AR IEKAISĪGĀM ZARNU SLIMĪBĀM}

Pacientiem ar iekaisīgām zarnu slimībām (IZS) regulārs dzelzs deficīta (DD) skrīnings var palīdzēt diagnosticēt DD agrīni, pirms attīstās dzelzs deficīta anēmija (DDA). Pētījumā galvenokārt aplūkota nepieciešamība pēc pirmā posma DD skrīninga pacientiem ar IZS, izmantojot laboratorijas pamatparametrus, tādus kā feritīnu un C-reaktīvo proteīnu (CRP). Pētījums atklāja, ka feritīna analīze tika nozīmēta tikai vienai trešdaḷai unikālo pacientu ar IZS piecu gadu periodā. Pirmā posma DD skrīnings parādīja, ka feritīna vērtību samazināšanās minētajā periodā tika konstatēta 56\% unikālo IZS pacientu, kas tika noteikts, izmantojot CRP un feritīnu vienas asins savākšanas laikā (viens nosūtījuma numurs). Neārstēts DD var izraisīt DDA, kā rezultātā samazinās hemoglobīna (Hb) vērtības. Mūsu pētījuma dati parādīja, ka Hb testi tika veikti $93 \%$ unikālo IZS pacientu piecu gadu laikā. Hb samazināšanās tika konstatēta $21 \%$ pacientu ar Krona slimību, 20\% pacientu ar čūlaino kolītu un 5\% pacientu ar neprecizētu neinfekciozu gastroenterītu un kolītu. Turpmāk skrīnings jāturpina, izmantojot citus markiierus, lai precizētu DD diagnozi, profilakses un ārstēšanas stratēǵijas. Turklāt ir nepieciešams vairāk pētījumu, lai noteiktu optimālas uztura stratēgijas DD profilaksei un/vai ārstēšanai pacientiem ar IZS. 